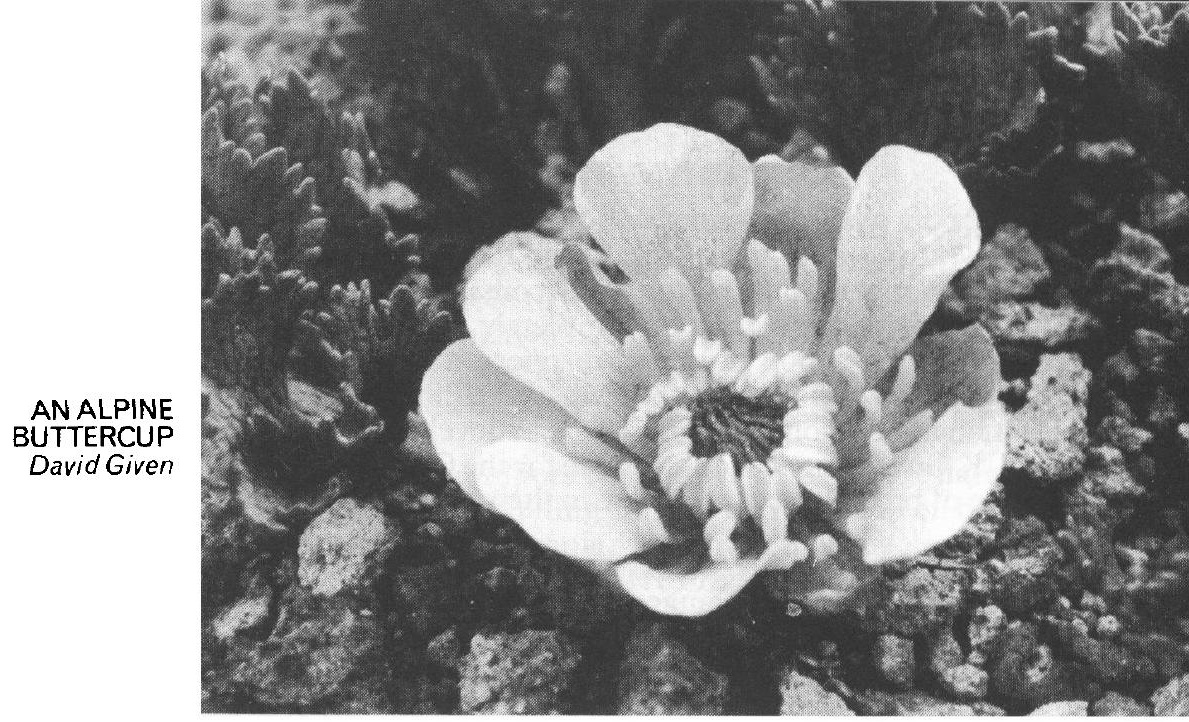

IUCN delegates in New Zealand assisted in the latest stage of the rescue operation for this beautiful golden-yellow endemic buttercup Ranunculus paucifolius, when more plants grown from seed were planted out in the reserve created to protect its only site, 2500 feet up in the mountains. Trampling by domestic stock and nibbling by sheep and hares had almost

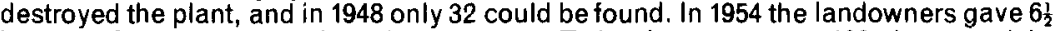
hectares for a reserve, and seeds were sown. Today there are some 400 plants, and the reserve is 'full', but it is hoped to extend it. This interesting relict plant is adapted to survive only in dry cold limestone areas. It produces only small amounts of seed which germinate slowly, and proved very difficult to cultivate, but botanists have now discovered the conditions in which it germinates freely.

\title{
IUCN Assembly in New Zealand
}

Some 440 people from 62 nations, some after a very long trek, assembled in New Zealand for the 15th General Assembly of the International Union for Conservation of Nature and Natural Resources, which met in Christchurch Town Hall on October 13-23. Much of the work, including the whole of the Technical Meeting, comprised a review of the World Conservation Strategy which IUCN, together with WWF and UNEP, launched in March 1980. The verdict on this was that a good start had been made towards its implementation, but that in many parts of the world it had so far made little impact. One of these parts is the United Kingdom, whose Government, recognising the impotence of the voluntary movement compared with, for instance, the farming and industrial lobbies, has safely been able to do precisely nothing. India, on the other hand, which is emerging as one of the Third World leaders of the environmental movement, and Oman among smaller nations are examples of those that take natural resource conservation seriously.

\section{Resolutions}

General Assemblies usually concern themselves with a whole host of broad general resolutions, and this one was no exception, tackling, for instance, renewable energy, genetic resources, and tropical moist forests, together with greatly daring, and for the first time - the menace of uncontrolled human population growth. More specific were resolutions calling for a cessation of 
commercial whaling (a notable advance on the previous call for a moratorium and one that steps outside the World Conservation Strategy) and no mineral extraction in the Antarctic 'until full consideration has been given to protecting the Antarctica environment completely from minerals activities'. Some 42 more detailed action points were referred to the IUCN Council for action; among these was a proposal from the ffPS that IUCN should assist in the creation of new conservation NGOs in developing countries, and another that the UK Government should ensure for the Cairngorm Mountains in Scotland a degree of protection appropriate to their international significance.

\section{Officers}

As far as domestic arrangements were concerned, Professor Mohammed Kassas, Egypt, and Dr Lee Talbot, USA were re-elected President and Director-General respectively, and Grenville Lucas, a member of ffPS Council, Chairman of the Species Survival Commission. Sir Peter Scott, ffPS President, received the John C. Phillips Medal, the third distinguished British recipient after Max Nicholson and the late Sir Frank Fraser Darling.

\section{The Members}

Membership was reported to have increased by 8 per cent since the 1978 Assembly, and comprised 54 States, 116 Government agencies, 279 national NGOs (non-governmental organisations) and 22 international NGOs, of which ffPS is one, and 7 affiliates. Three new State members are Costa Rica, Jordan and Qatar. The representation covers 30 African countries, 13 Central and South American, 6 North American and Caribbean, 17 East Asian, 10 West Asian, 5 Australian and Oceanic, 7 East European and 22 West European.

The General Assembly in 1984 will be in Costa Rica or Switzerland.

\section{BLACK STILTS RELEASED}

With numbers in the wild down to about 50, New Zealand's endemic black stilt Himantopus novae-zelandiae is highly endangered. The Wildlife Service is taking eggs that are likely to be lost anyhow, and releasing young birds in the original wild habitat in the Mackenzie Country in South Island. During the Assembly three young birds were released into a predatorproof enclosure fenced by the Royal Forest and Bird Protection Society, from which they would be released into the open. The birds emerged cautiously from their travelling box, ceremonially opened to clicking cameras by the Director General of IUCN, Dr Lee Talbot, but took to the water with every appearance of immense delight.

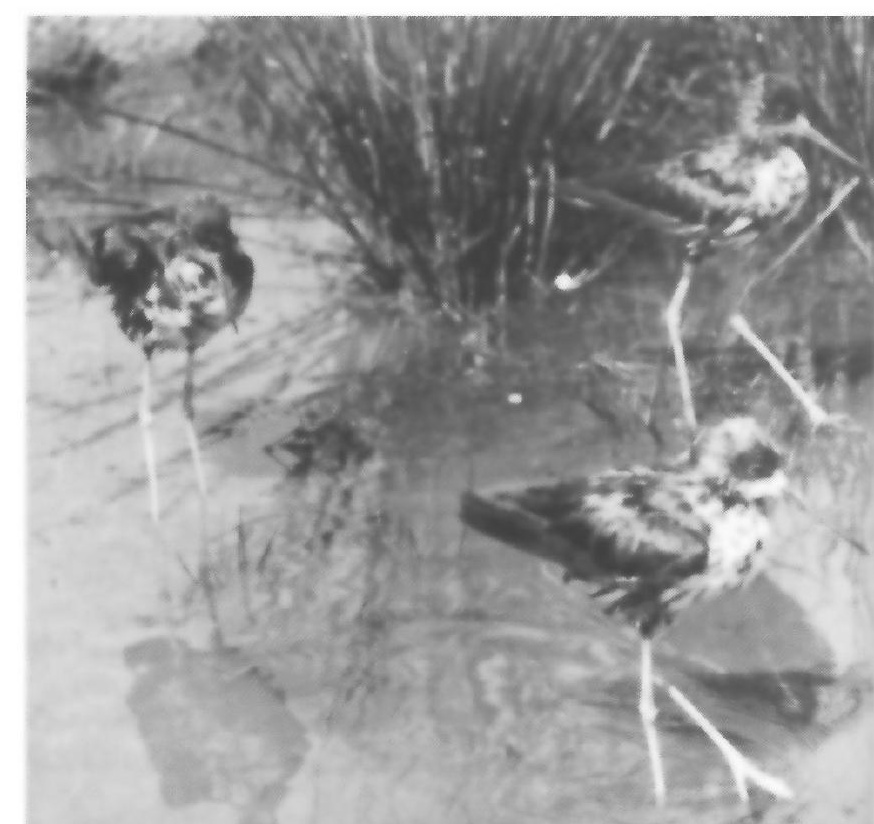

